\title{
The Existence of Penting Instruments in Gamelan Ensemble at Karangasem Regency, Bali
}

\author{
Pande Made Sukerta ${ }^{1 *}$ I Nyoman Sukerna ${ }^{1} \quad$ Ketut Gura Arta Laras ${ }^{2}$ \\ 1.Faculty of Performing Art, Indonesia Institute of the Arts Surakarta. Ki Hajar Dewantara Road, No.19 \\ Kentingan, Jebres, Surakarta, Central Java, Indonesia \\ 2.Faculty of Art and Design, Indonesia Institute of the Arts Surakarta. Ring Road Mojosongo, Jebres, Surakarta, \\ Central Java, Indonesia
}

\begin{abstract}
Penting gamelan ensemble was one form of Balinese gamelan ensembles that lived and developed in the eastern part of Bali, namely the Karangasem area. In this penting gamelan ensemble, penting types of instruments were very dominant both in terms of their usage and in terms of their musicality. Penting instrument was the only type of Balinese gamelan instrument that was played by picking the strings, while other types of Balinese gamelan instruments were mostly played by beating (percussion instruments). In Karangasem, there were several forms of penting gamelan ensembles. In an ensemble the number of penting instruments was not fixed. In fact, there was one music group which included penting instruments as the only instrument that functioned as melody. Another condition revealed was the small number of young people who were interested in learning to play penting instruments. They were more interested in learning other types of instruments. In addition there were also only a small number of penting instrument makers, because it wass rare for people who want to posess penting instrument. By looking at such situations faced by penting instruments and penting gamelan ensembles, it could be said that the existence of this type of instrument was very alarming.
\end{abstract}

Keywords: Penting instruments, gamelan ensemble, Karangasem Regency.

DOI: $10.7176 / \mathrm{ADS} / 73-03$

Publication date:May $31^{\text {st }} 2019$

\section{Introduction}

Karawitan or often referred to as 'gamelan', was a form of the life necessities for Balinese people. Balinese people saw gamelan not only as a means of entertainment, for fun, or partying, but more than that, gamelan was seen as a means to meet spiritual needs. Therefore the existence of gamelan in Bali had become very meaningful in the life of Balinese people. Broadly speaking, the function of Balinese arts was for the purposes of offerings and performances. The offerings were addressed to Ida Sanghyang Widhi or the Supreme Lord, so that the use of gamelan was included in the series of ceremonies, while the performances were aimed more at human needs in their life. Both of these functions could be proven by the existence of various types of Balinese gamelan ensembles that lived and developed in remote areas in Bali. The use of gamelan ensembles in ceremonies was a necessity that was covered by the concept of Panca Gita and Desa Kala Patra. Panca Gita was a concept in Hinduism teachings, which meant that in the implementation of the ceremony there must be sound elements from five sound sources, namely mantram, genta, kentongan, vocal (kidung), and gamelan. The ensemble type applied in the ceremony used the concept of the Desa Kala Patra, meaning that the use of gamelan ensemble in the implementation of the ceremony was adjusted to the abilities and habits that had been done before (tradition). In Bali there were around 38 types of gamelan ensembles and approximately ten types of new gamelan ensembles made by contemporary artists. Each of these entire types of gamelan ensembles had different shapes, functions, instruments, repertoires, and aesthetics. Penting gamelan ensemble was included in these Thirty-eight gamelan ensembles.

Based on observations, I found that penting gamelan ensemble had not used 'fixed' types of instruments, meaning that one penting gamelan group used different types and numbers of instruments with other penting gamelan groups. Thus, the life of penting gamelan ensemble could be considered less developed than the other gamelan ensembles which in general each of the gamelan ensembles used almost the same type and number of instruments.

In penting gamelan ensemble, penting was a very dominant instrument in both the use of instruments and musicality. This was like in gambang gamelan ensemble, which meant that in that gamelan ensemble, physically and musically, gambang was the most dominant instrument. But in reality, penting instruments could also function as a complement, not function as a basic instrument.

Penting instruments had unique shape. This instrument existed and developed in Bali especially in the eastern part of Bali, namely Karangasem. Besides being in the form of instruments, penting was also a term for the gamelan ensemble called penting gamelan ensemble.Unfortunately penting gamelan ensemble was not widely known by the public, especially in Karangasem area. This gamelan ensemble was not even well known among Balinese people. Thus, penting instrument and penting gamelan ensemble, were considered rare, because 
only Karangasem had penting gamelan ensemble. In addition, the number of penting gamelan ensemble was also small.

The construction of penting instrument was very interesting. Almost all parts of this instrument were made of long wood of a certain size. Apart from the unusual shape, penting instrument was the only type of instruments in Balinese music that was played by picking the source of the sound, namely the string.

Regardless of the uniqueness and elegance possessed by penting instruments, the condition of penting instrument makers was very alarming. There were not many young people who were interested in learning this musical instruments eventhough other Balinese gamelan instruments attract many people to learn about the making and learning playing techniques. These were the problems that needed to be addressed immediately for the development of penting instruments in the future.

With such conditions, we should take concrete actions so that penting instruments were not eroded by the progress of the times.

\section{Discussion}

Penting instrument was the only type of Balinese gamelan instruments that was played by picking, while other types of Balinese gamelan instruments were mostly played by beating (percussion instruments). Penting instrument used strings as the sound source. There were nine strings on each penting instrument, consisting of six strings number two and the other three strings use the number four string. The nine strings were tuned in the same tone. In one penting instrument there were sixteen keys (position for pressing the tone), so that it could cause a minimum of two tunings, namely slendro and pelog.

The existence of penting instruments could be in a form of ensemble or gamelan ensemble called penting gamelan ensemble and could also be single instrument.

\section{a. The formation of gamelan ensemble}

As explained above, penting gamelan ensemble had not used penting instruments in certain variants and quantities. This meant that one penting gamelan group with other penting gamelan groups used different variants and different penting instruments. Even penting instruments were only used as a complement. For more details, we could look at the variants of penting gamelan ensembles below.

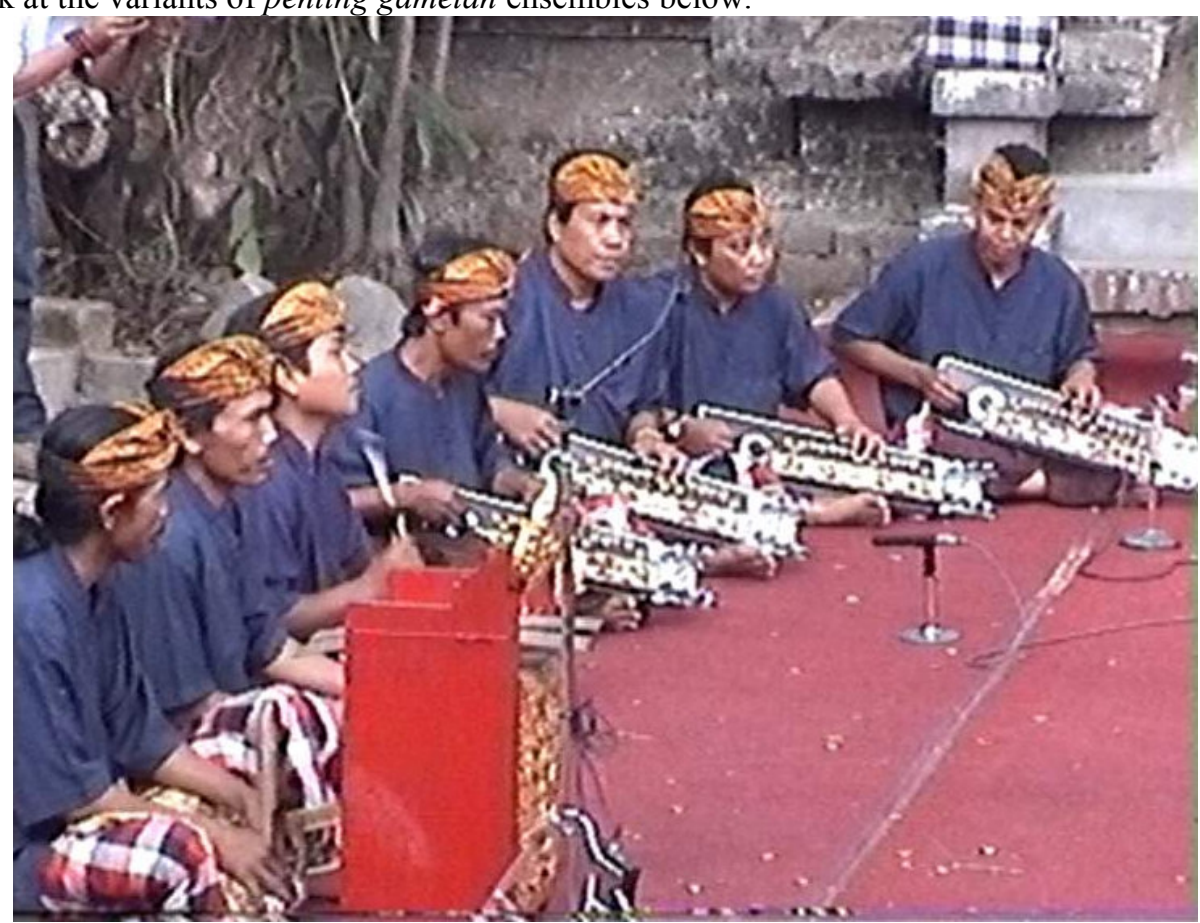

Penting gamelan ensemble (Doc. Pande Made Sukerta)

Picture of penting gamelan ensemble above showed that one penting gamelan group used several penting instruments and still used other variants of instruments such as the kendang, gong pulu, suling, and ceng-ceng gecek instruments. Regarding the formation of this penting gamelan ensemble, the number of instruments was dominated by penting instruments. In terms of musical groups, it was also dominated by the sound of penting instruments. In traditional musical performance, the intro part of was presented by one of penting instrument musicians, while the tempo and completion of the song was performed by kendang instrument player.

In other variants of gamelan ensemble, penting instruments acted as melody presenters. The picture could be seen below. 


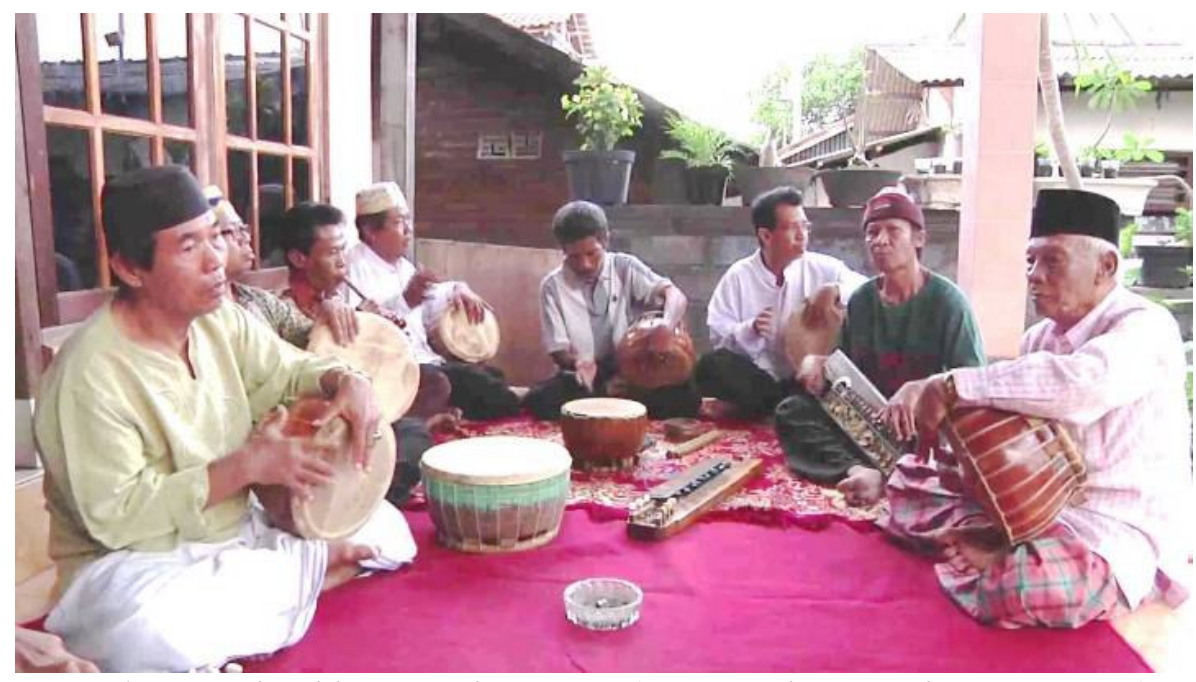

Terebang music with penting instrument (Doc. I Gede Putu Wiranegara, 1999)

In the gamelan ensemble above, penting instrument was the only instrument variant that served as a melody, while other variants of instruments were tarebang instruments which were played by being hit and in charge of maintaining rhythm. Musically, the traditional song performances in the ensemble above was dominated by tarebang instruments. In traditional song performance, the kawitan (intro) part in traditional song was presented by one of penting instrument players, while the tempo setting and closing of the traditional song performance were performed by one of the tarebang instrument players. Performances of penting instruments could also be used in the gamelan ensemble as shown below.

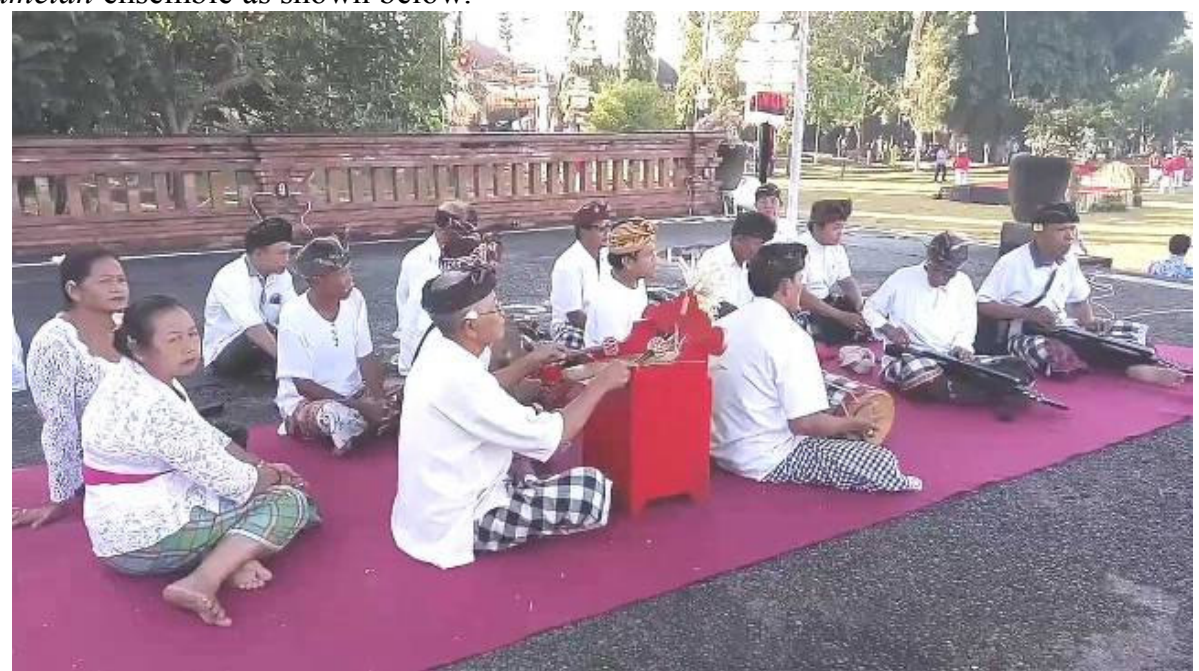

Penting gamelan ensemble (Source: https://www.youtube.com/watch?v=zTIunprrtdE)

The picture of penting gamelan ensemble above showed that a set of penting gamelan used several penting groups and was added with a variety of other instruments such as kendang instrument, gong pulu, and ceng-ceng gecek. In the formation of penting gamelan ensemble, the number of instruments was dominated by the use of penting instruments. Thus the musical presentation was dominated by the sound of penting instruments. In traditional song performance, the intro part in traditional song was presented by one of the penting instrument players, while the tempo setting and the ending of traditional song performance were performed by the kendang beater. The following was a simpler formation of penting gamelan ensemble. 


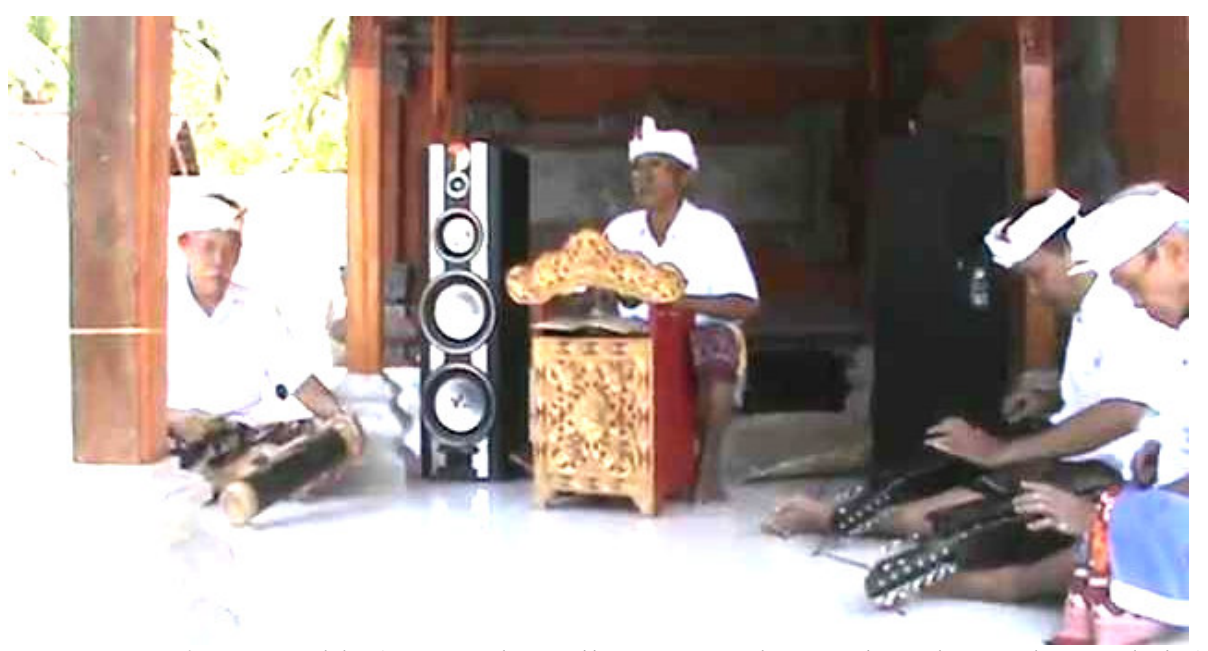

Penting gamelan ensemble (Source: https://www.youtube.com/watch? $\mathrm{v}=9 \mathrm{dZBu}-\mathrm{kzjw}$ )

The image of penting gamelan ensemble above were penting gamelan ensemble which was relatively smaller compared to other penting gamelan ensembles. This penting gamelan ensemble consisted of timbung, gong pulu, and penting instruments. In musical terms, the beat or sound of penting instruments was very dominant in presenting melodies. In the traditional song performance, part of the traditional song was presented by one of the penting instrument players, while the tempo and ending of the traditional song was performed by one of the penting instrument players.

In addition to the penting gamelan ensemble that had been explained, there was also penting gamelan ensemble that only used 2 (two) penting instruments. The gamelan ensemble was shown in the picture below.

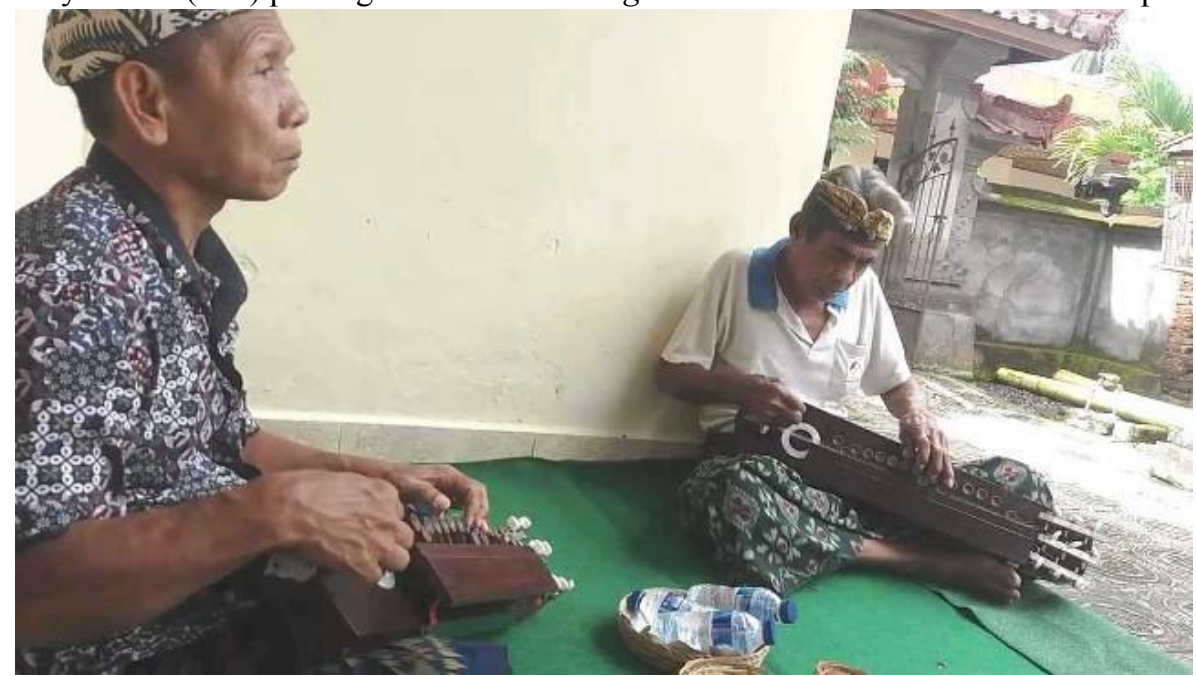

Penting gamelan ensemble (Source: https://www.youtube.comwatchv=BZxug-nd6RA)

In the picture above, the size of penting gamelan ensemble was smaller than other penting gamelan ensembles. The penting gamelan ensemble used only two penting instruments. Each penting instrument had distinct tone patterns in one composition. The difference in the tone patterns would produce a series of tones. In a traditional Balinese musical performance the intro music was presented by one of the penting instrument players, while the tempo and ending of the musical performance was performed by one of the penting instrument players by giving certain codes.

\section{b. Solo Instrument}

'Solo' meant alone, in this case as solo instrument meant that penting instruments could be presented or could present musical performances independently. Thus it could be said that penting instruments could not only form an ensemble, but also could present a solo musical performance (independent music performance). Thus, a penting instrument as a solo instrument means that this instrument could be played or could present music performances independently and fulfill musical rules. There had been many music enthusiasts who presented penting instruments independently. The pictures below could give explanations. 

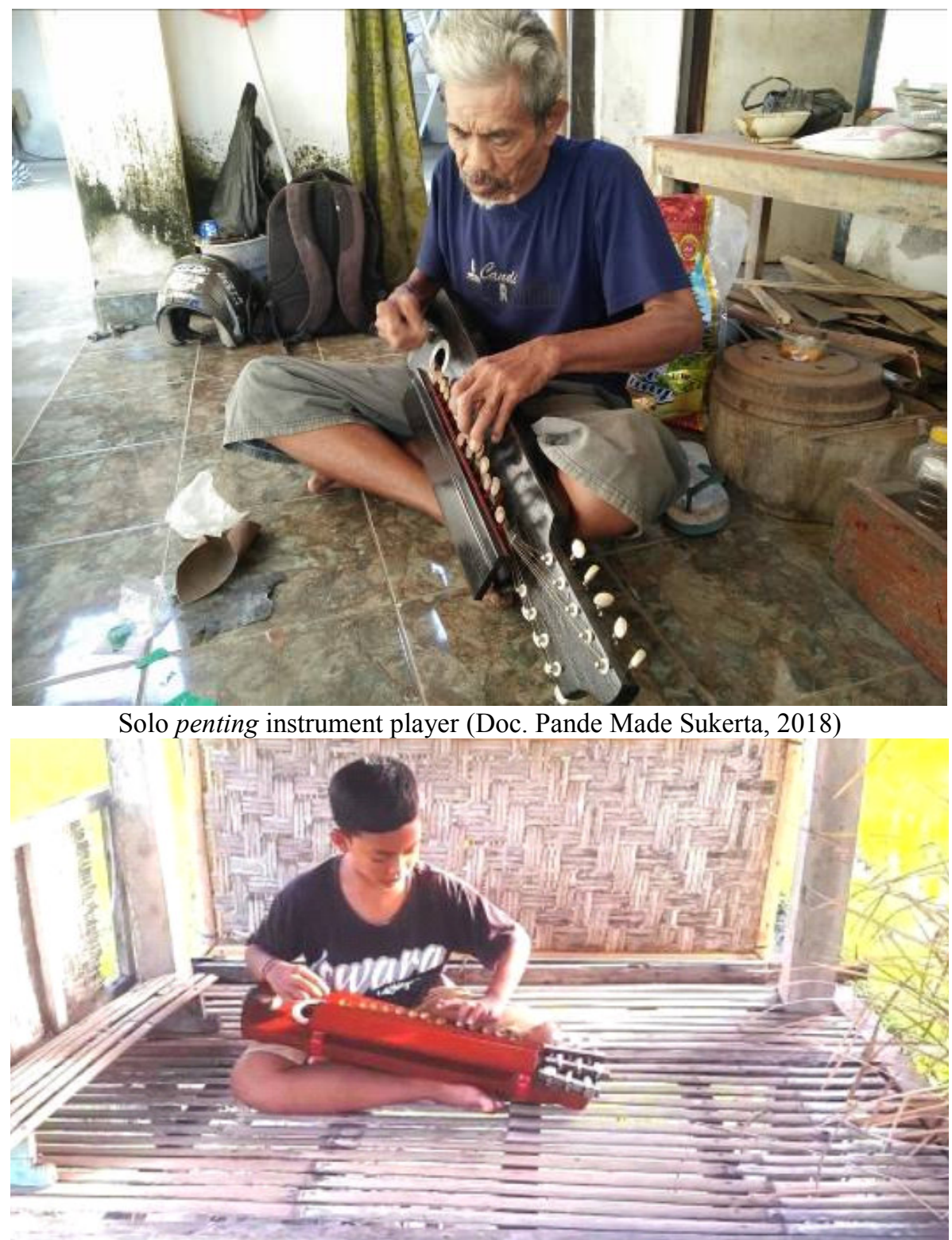

Solo penting instrument player (Source: https://www..youtube.comwatchv=GQZjf1Ghl7Y)

By looking at the musical potential of penting instruments above, it could be said that penting instruments had the potential to be developed in Bali, not only in Karangasem area (eastern Bali) but in all regions of Bali. Its development was in the form of an ensemble or as a single instrument.

\section{c. Special instrument}

With the large number of gamelan ensembles in Bali coupled with many types and variants of instruments used in each gamelan ensemble, according to my observations, the types of instruments used in each gamelan ensemble in Bali were dominated by percussion instruments made from bronze. There were only one type of friction instrument, the rebab instrument, while instrument that were played by picking were only one type of instrument, penting instrument. When we considered at the use of penting instruments in gamelan ensemble, the interest of younger generation in learning into it, and the dissemination of abilities for the survival of this type of musical performance, it could be said that penting instruments were special and rare types of instruments.

Penting instruments were considered as special instruments due to several things as followed.

1) Penting had distinctive shape, very different from other types of instruments. This instrument was longitudinal shaped using nine strings of two sizes. The nine strings used the same tone.

2) Penting was the only instrument that was played by picking. It should be noted that the types of instruments used in Balinese gamelan ensemble were mostly played by beating (percussion instruments). Besides being played by picking, the desired tone and sound was also obtained by pressing the strings. In one press, the nine strings used would get all the pressure. 


\section{Conclusion}

Based on the discussion above, we could conclude that penting instrument was the only type of Balinese gamelan instrument that was played by picking. This type of instrument used nine strings with two different sizes, but had the same tone setting. The composition of penting gamelan ensemble had not been fixed. That was, the types of instruments in each of penting gamelan ensembles were not the same, and even penting instruments were one type of instrument used in terebang music. The younger generation was less interested in learning penting instruments, penting instrument makers were also very rare. With such conditions, the existence of penting gamelan instruments and ensembles in Bali, especially in Karangasem was very alarming.

\section{References}

Anom Ranuara, Ida Bagus, dkk. 1984/1985. Teater Di Bali Dari Masa Ke Masa. Denpasar: Departemen Pendidikan dan Kebudayaan, Direktorat Jenderal Kebudayaan, Proyek Pengembangan Kesenian Bali.

Aryasa, I W.M. 1976/1977. Perkembangan Seni Karawitan Bali. Denpasar: Laporan Proyek Sasana Budaya Bali. dkk. 1984/1985. Pengetahuan Karawitan Bali. Denpasar: Departemen Pendidikan dan Kebudayaan, Direktorat Jenderal Kebudayaan, Proyek Pengembangan Kesenian Bali.

Atmaja, Jiwa (ed.). 1988. Puspanjali Persembahan Untuk Prof. Dr. Ida Bagus Mantra. Denpasar: Kayumas.

Balyson. 1934. "Gong-Gede (Kebijar) Samboengan Bhawanagara No. 11-12", dalam Bhawanagara, Soerat boelanan oentoek memperhatikan peradaban Bali, Juni, Tahoen III.

Balyson. 1934. Gong-Gede (Kebijar). Samboengan Bhawanagara No. 11-12. Dalam Bhawanagara Soerat boelanan oentoek memperhatikan peradaban Bali. Juni, Tahoen III.

1934. "Gending Gong", dalam Bhawanagara, Soerat boelanan oentoek memperhatikan peradaban Bali. No. 4-5 September-Oktober, Tahoen IV.

Bandem, I Made. 2013. Gamelan Bali Di Atas Panggung Sejarah. Denpasar: BP STIKOM BALI

Dinas Kebudayaan Propinsi Bali. 2003. Inventarisasi Seni Wali Di Daerah Bali. Dinas Kebudayaan Propinsi Bali.

Rai S., I Wayan, dkk. 1999. “Keragaman Laras (Tuning System) Gamelan Gong Kebyar”. Denpasar: Sekolah Tinggi Seni Indonesia.

Rembang, I Nyoman, dkk. 1994/1995. Deskripsi Karawitan Gong Luang. Denpasar: Proyek Pembinaan Kesenian Kanwil Depdikbud Propinsi Bali.

1977. "Daftar Klasifikasi Gamelan Bali”. Makalah untuk serasehan besar karawitan Bali. Surakarta: Pusat Pengembangan Kebudayaan Jawa Tengah.

Sukerna, I Nyoman. 2006, "Gender Wayang: Barungan Gamelan Bali Kelompok Tua". Vol.4 No.1 Jurnal DEWARUCI, Surakarta: Pascasarjana STSI Surakarta . 2008. "Musikalitas Gamelan Jegog Bali”. Jurnal DEWARUCI, Surakarta: Pascasarjana ISI Surakarta

Sukerta, Pande Made. 1997/1998. Peta Karawitan Bali di Kabupaten Buleleng. Jakarta: Laporan Proyek Pengembangan Media Kebudayaan, Departemen Pendidikan dan Kebudayaan. 1999. "Peta Kesenian Bali Di Kabupaten Jembrana". Jembrana: Pemerintah Daerah Tingkat II Jembrana.

2001. "Gong Kebyar Gaya Buleleng Cerminan Budaya Masyarakat Bali Utara" (tesis). Denpasar: Program Studi Kajian Budaya Program Pascasarjana, Universitas Udayana Denpasar (UNUD). 1997. Penelitian "Peta Karawitan (Kesenian) Bali di Kabupaten Badung", Proyek Pemerintah Daerah Tingkat II Kabupaten Badung Propinsi Bali. 1997/1998. Peta Karawitan Bali di Kabupaten Buleleng. Jakarta: Laporan Proyek Pengembangan Media Kebudayaan, Departemen Pendidikan dan Kebudayaan. 2001. Buku Jenis-jenis Tungguhan Gamelan Bali, ISBN : 979-950687-3-2, Penerbit : Proyek Pengembangan Media Kebudayaan, Direktorat Jenderal Kebudayaan, Departemen Pendidikan Nasional Republik Indonesia. 2010. Tetabuhan Karawitan Bali I, Surakarta: ISI Press Solo. dan I Nyoman Sukerna. 2018. Buku Ajar Pembuatan Tungguhan Penting. Surakarta: ISI Press.

Supanggah, R. 2003. "Keragaman adalah Berkah". Makalah ini disampaikan pada Serial Seminar Internasional Seni Pertunjukan Indonesia Seri III 2002-2004 bertema Diversitas dan Pluralitas Kebudayaan dan Seni Pertunjukan” 21 dan 23 Juli 2003. Surakarta: Sekolah Tinggi Seni Indonesia (STSI).

Tusan, Pande Wayan. 2001. Selonding Tinjauan Gamelan Bali Kuna Abad X-XIV (Suatu Kajian Berdasarkan Data Prasasti, Karya Sastra dan Artefak). Denpasar: Dinas Kebudayaan Propinsi Daerah Tingkat I Bali. 